\title{
Acute Soft Skull Syndrome in an Adult Male with Sickle Cell Anemia in Sudan: A Case Report
}

\author{
Ziryab Imad Taha ${ }^{1,2 *}$, Sulafa Eisa Mohammed $^{3}$, Mohammed Elmujtba Adam Essa ${ }^{1,4^{*}}$, \\ Walaa Mohamed Elsid ${ }^{2}$, Mustafa Mohamed Ali Hussein ${ }^{1,4}$, \\ Sherihan Mohammed Elkundi Osman ${ }^{4,5}$, Hussein Osman Ahmed ${ }^{4}$, \\ Mutwaly Defealla Yousif ${ }^{1,4}$ and Abdelkareem A. Ahmed ${ }^{1,6^{*}}$
}

\begin{abstract}
${ }^{1}$ Department of Clinical Medicine, Medical and Cancer Research Institute (MCRI), Nyala, Sudan; ${ }^{2}$ Department of Internal Medicine, Faculty of Medicine, University of Bahri, Khartoum, Sudan; ${ }^{3}$ Department of Internal Medicine, National Ribat University, Khartoum, Sudan; ${ }^{4}$ Department of Internal Medicine, Faculty of Medicine, AlFashir University, AlFashir, Sudan; ${ }^{5}$ Department of Molecular Medicine, Institute of Endemic Diseases, University of Khartoum, Khartoum, Sudan; ${ }^{6}$ Department of Physiology and Biochemistry, Faculty of Veterinary Science, University of Nyala, Nyala, Sudan
\end{abstract}

\begin{abstract}
Acute soft skull syndrome is an uncommon complication of patients with sickle cell anemia. Here, we report a case of an adult patient in Sudan with the acute soft syndrome, with our aim of providing more knowledge on this type of complication. The 20-year old patient, with a known history of sickle cell anemia, presented with a 1-day history of headache and joint pain. The complaint continued after admission, with increasing headache severity and development of rapid skull swelling, which indicated the rare sickle cell disease complication known as an acute soft head syndrome. Conservative management resulted in good response and rapid recovery of this case of acute soft skull syndrome with sickle cell anemia mainly related to skull infraction.
\end{abstract}

Introduction

Sickle cell disease (SCD) ${ }^{1}$ includes a group of related genetic diseases affecting hemoglobin structure, ${ }^{2}$ and is considered the most common genetic blood disorder among children. ${ }^{3}$ SCD frequently occurs in individuals whose ethnic origin is Africa, ${ }^{4}$ Middle East, ${ }^{5}$ Asia, ${ }^{6}$ Southern Europe, ${ }^{7}$ Central or South America, ${ }^{8}$ or the Caribbean. ${ }^{9}$ Sudan includes mosaic ethnic diversity that ranges from Afro-Arab and Arab to African tribal. ${ }^{4}$ This ethnic diversity includes groups with Negroid genetic features, with a recognized history in

Keywords: Adult; Acute soft skull syndrome; Sickle cell anemia; Conservative management.

Abbreviations: CT, computed tomography; MRI, magnetic resonance imaging; SCD, sickle cell disease.

Received: September 21, 2019; Revised: October 17, 2019; Accepted: November 29, 2019

${ }^{*}$ Correspondence to: Mohammed Elmujtba Adam Essa Adam, Medical and Cancer Research Institute (MCRI), Department of Clinical Medicine, Faculty of Medicine, AlFashir University, AlFashir, Sudan. Tel: +249907009378, E-mail: Awadali818@yahoo.com; Ziryab Imad Taha, Department of Internal Medicine, Faculty of Medicine, University of Bahri, Khartoum, Sudan, Tel: +249912129921, E-mail: Ziryab2008@ yahoo.com; Abdelkareem Abdallah Ahmed, Department of Physiology and Biochemistry, Faculty of Veterinary Science, University of Nyala, Nyala, P.O. Box: 155 Nyala, Sudan. Fax:+249711833123, E-mail: kareemo151@gmail.com

How to cite this article: Taha ZI, Mohammed SE, Essa MEA, Elsid WM, Hussein MMA, Osman SME, Ahmed HO, Yousif MD, Ahmed AA. Acute Soft Skull Syndrome in an Adult Male with Sickle Cell Anemia in Sudan: A Case Report. Exploratory Research and Hypothesis in Medicine 2019;4(4):90-93. doi: 10.14218/ ERHM.2019.00024 areas such as Nilotes and Nuba. ${ }^{10}$

Acute skull soft syndrome is an uncommon complication of sickle cell anemia. ${ }^{11}$ The pathogenesis and mechanism underlying the complication of acute skull soft syndrome is not fully understood. In addition, no information has been gained from the previous studies of acute skull soft syndrome for suffers in Sudan. The case of such presented herein is thus novel and of particular importance to Sudanese clinicians, ${ }^{12}$ and we hope it will serve to increase knowledge and kindle awareness of this complication in Sudan.

\section{Case Report}

A 20-year old male with a known history of sickle cell anemia, diagnosed at the age of 2 years-old, came to our clinic at Almawada (a private hospital) on May 18, 2019. The patient complained of headache and generalized joint pain that had begun 1 day prior to clinic presentation. The patient described the headache as constant, with mild frontal pain and not preceded by an aura nor associated or aggravated by anything, and partially relieved by paracetamol tablets. He denied any visual changes, vomiting, altered level of consciousness, neck pain, or variation of headache with positional changes or during the hours of the day. He also reported isolated joint pain involving wrists, knees and hips. The pain had severity score of $6 / 10$ (according to self-judgment) and was dull in quality but not interfering with movement. There was moderate grade fever and the pain had intermittent association with nausea, but no 
Table 1. Lab investigations and findings for the patient

\begin{tabular}{llll}
\hline Date & Investigation & Result & Reference value \\
\hline $18 / 5 / 2019$ & Blood urea nitrogen & $141 \mathrm{mg} / \mathrm{dL}$ & $10-50 \mathrm{mg} / \mathrm{dL}$ \\
& Serum creatinine & $18.5 \mathrm{mg} / \mathrm{dL}$ & $0.7-1.4 \mathrm{mg} / \mathrm{dL}$ \\
& Serum Na+ & $139 \mathrm{~nm} / \mathrm{L}$ & $131-149 \mathrm{~nm} / \mathrm{L}$ \\
& Serum K+ & $3.6 \mathrm{~nm} / \mathrm{L}$ & $3.1-5 \mathrm{~nm} / \mathrm{L}$ \\
& Random blood glucose & $141 \mathrm{mg} / \mathrm{dL}$ & $79-140 \mathrm{mg} / \mathrm{dL}$ \\
& Immunochromatographic (ICT) for malaria & Negative & $131-149 \mathrm{~nm} / \mathrm{L}$ \\
$20 / 5 / 2019$ & Serum Na+ & $137 \mathrm{~nm} / \mathrm{L}$ & $3.1-5 \mathrm{~nm} / \mathrm{L}$ \\
& Serum K+ & $3.6 \mathrm{~nm} / \mathrm{L}$ & $4-10 \mathrm{cells} / \mathrm{cumm}$ \\
& White blood cells & $12.7 \mathrm{cells} / \mathrm{cumm}$ & $3.8-5 \mathrm{mill} \mathrm{cells} / \mathrm{cumm}$ \\
& Red blood cells & $2.01 \mathrm{mill}$ cells/cumm & $12.5-15.5 \mathrm{~g} / \mathrm{dL}$ \\
& Blood hemoglobin & $6.5 \mathrm{~g} / \mathrm{dL}$ & $78-98 \mathrm{fl}$ \\
& Mean corpuscular volume & $98 \mathrm{fl}$ & $150,000-450,000$ \\
& Platelets & $98,000 \mathrm{cells} / \mathrm{cumm}$ & $\mathrm{cells} / \mathrm{cumm}$ \\
& Blood urea nitrogen & $25 \mathrm{mg} / \mathrm{dL}$ & $15-45 \mathrm{mg} / \mathrm{dL}$ \\
& Creatinine & $1.5 \mathrm{mg} / \mathrm{dL}$ & $0.7-1.4 \mathrm{mg} / \mathrm{dL}$ \\
\hline
\end{tabular}

shivering or rigger. The patient also reported a burning sensation during micturition. There were no complaints involving any other organ systems.

The patient had a history of multiple previous hospital admissions, due to sickle cell crises. He had no history of diabetes mellitus, hypertension or any similar conditions, but he had been diagnosed 1 month previous with gallstone ("not operated"). The patient was on regular folic acid tablets, $5 \mathrm{mg}$ daily, and not known to be allergic to any type of medication. On examination, the patient looked ill and in pain, and was pale and jaundiced. Vital signs were all within normal parameters, except for the body temperature at $38{ }^{\circ} \mathrm{C}$. Blood pressure was $120 / 80$ and heart rate was 70 beats $/ \mathrm{m}$. The patient was fully conscious and oriented when the central nervous system tests were performed. The Mini-Mental State Examination (commonly referred to as the 'MMSE') score was 30/30. All cranial nerves were intact, and Kernig's and Brudzinski's signs were negative.

Upper limbs showed no muscle wasting or fasciculations, and there was intact normal tone sensation; power was grade 5, and deep tendon reflex was +2 bilaterally. The lower limbs showed no muscle wasting or fasciculations, normal tone and intact sensation; power grade was 5, deep tendon reflex was +2 bilaterally, and gait was normal. Musculoskeletal examination of hands showed no swelling, tenderness, deformities, muscle wasting, skin rash or signs of dactylitis, and normal temperature and intact radial pulses. Phalen's test was negative, with both knees and hips showing not swelling nor hotness but tenderness was present; the range of movement was normal. The cardiovascular examination also showed normal first and second heart sounds, with no murmurs or signs of heart failure. Clear breath sounds were heard bilaterally in chest examination. Results from blood sample testing for complete blood count, renal function and blood glucose are summarized in Table 1. Upon admission, the patient was immediately begun on intravenous normal saline (1 L/8 hours) with ciprofloxacin infusion (200 $\mathrm{mg}$ intravenously every 12 hours), tramadol tablets (once per day), paracetamol infusion ( $1 \mathrm{~g} / 6$ hours), and $4 \mathrm{U}$ of packed red blood cells. On the third day of admission, the headache reached its maximum, being associated with scalp swelling and tenderness (Fig. 1). There was no loss of consciousness, visual change, projectile vomiting or neck stiffness. The patient denied history of head trauma, and stated he had never experienced such symptoms before. Again, the patient was negative for Kernig's and Brudzinski's signs. Brain magnetic resonance imaging (MRI) was conducted and revealed no abnormalities (Fig. 2). The diagnosis was made clear as soft skull syndrome. The patient was treated with conservative management of intravenous normal saline $(1 \mathrm{~L} / 8$ hours $)$ and pethidine injection (50 mg twice every day). After two days, the patient fully recovered and was discharged.

\section{Discussion}

$\mathrm{SCD}$ is considered to be one of the most common causes of chronic anemia among pediatric patients of African descent. ${ }^{13}$ Chronic anemia, as in our case, leads to an increase in the demands of blood production and development of an extramedullary or intramedullary hematopoiesis. ${ }^{14}$ As such, chronic anemia is linked with elevated cardiac output and increased blood flow velocity, resulting in arterial tortuosity in many cases. ${ }^{15,16}$

Acute soft skull syndrome is a rare manifestation of SCD, and the pathogenesis is not clearly understood, although it is believed to be related to infraction of the skull due to expansion of intramedullary hematopoietic tissues leading to disruption of the outer and inner skull margins and in turn resulting in softening of cortical bones. ${ }^{17}$ The differential diagnosis of a patient with acute soft head syndrome must include other causes of hematoma, such as trauma (which our patient had no history of), bleeding diathesis (in the present case, the platelet count and bleeding profile were within the normal range), and intracranial pressure (we excluded by the absence of any related features, such as altered level of consciousness, vomiting or visual changes). Clinical examination will also exclude any relative causes of skull swelling, such as lymph node enlargement due to any reason.

MRI and computed tomography (CT) scans of the skull have an important role in the differential diagnosis of sicker patients with acute soft swelling, as they are both able to detect bone infarction. ${ }^{18}$ MRI, However, is more sensitive than CT in detection of bone infraction. ${ }^{18}$ The presented patient underwent MRI and showed diploic space marrow signal changes consistent with known disease, which overall indicated an unremarkable finding. A contract-enhanced MRI will demonstrate an area of heterogeneous and rim-like enhancement, ${ }^{18}$ and $\mathrm{T} 2$-weighted and short-inversion time inversion recovery MRI can detect areas of the high- 


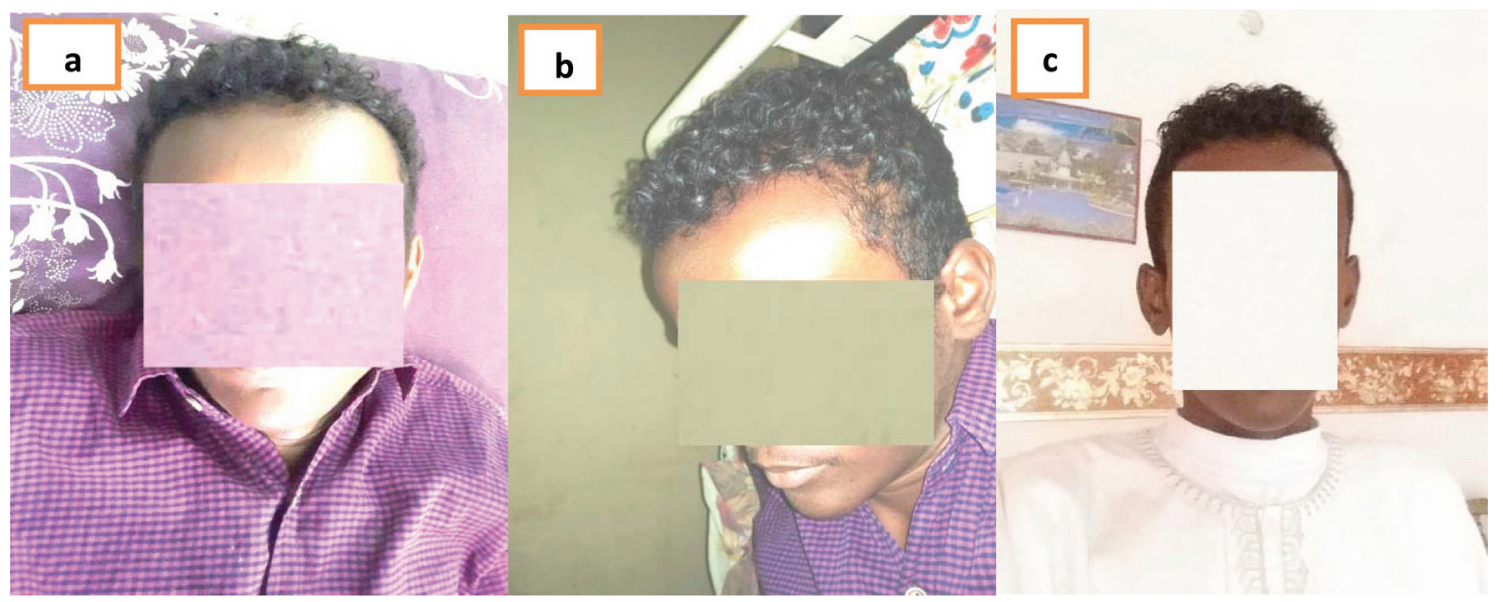

Fig. 1. During and after recovery from the acute attack of soft skull syndrome. (a) and (b) shows the patient with acute soft skull syndrome. (c) Shows the patient after recovery.

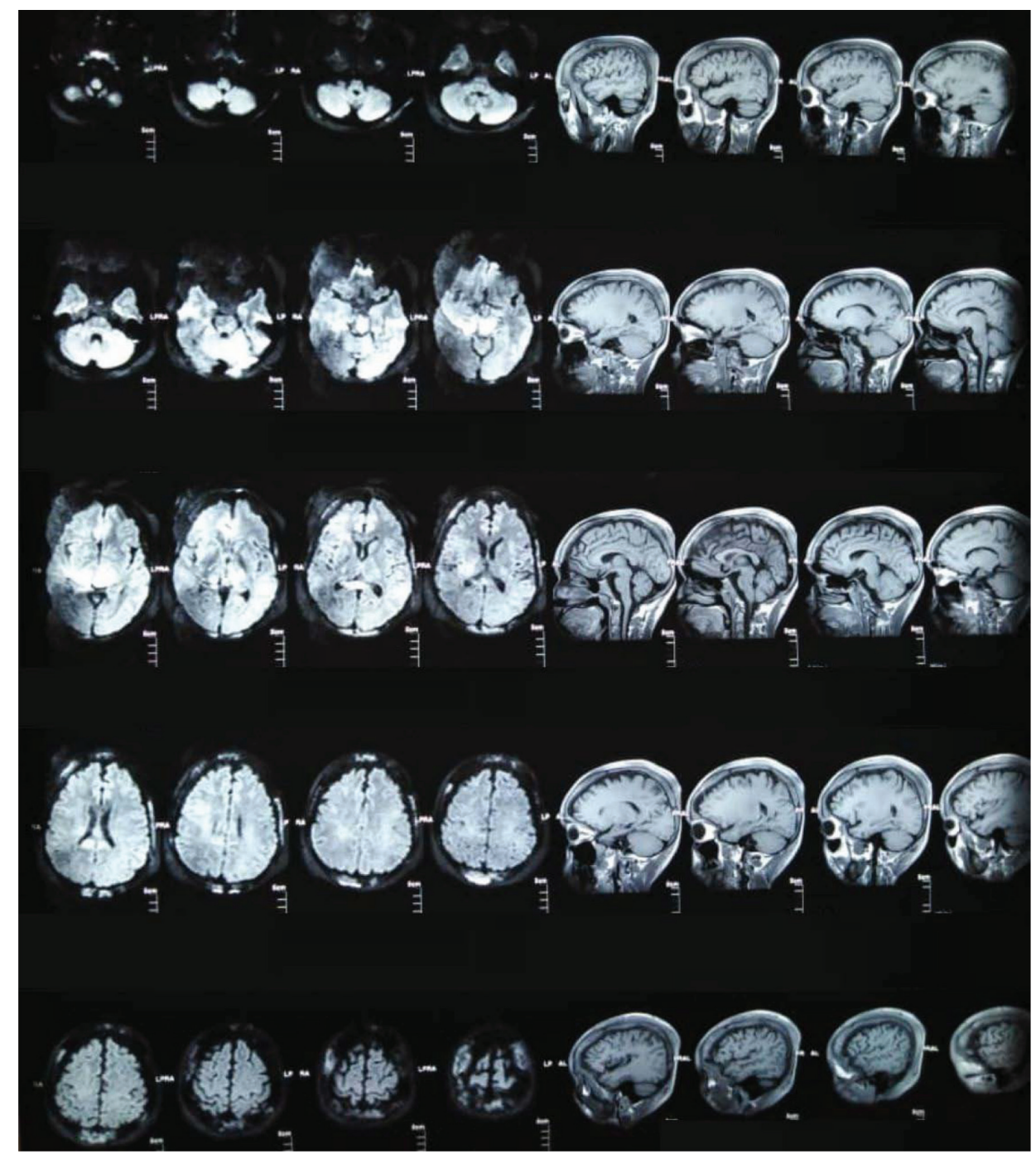

Fig. 2. Brain magnetic resonance imaging scans of the patient, indicating left maxillary polypoid sinusitis and diploic space marrow signal changes consistent with known disease. In conclusion: unremarkable study. 
intensity bone marrow infarction and edema. ${ }^{18}$ Although, neither one of those investigations could afforded by our patient.

Acute soft head syndrome due to sickle cell anemia is well known to be resolved by the same treatment of other sickle cell crises, that being conservative management (intravenous fluids and analgesics). ${ }^{18}$ Our patient did very well after receiving the intravenous fluids and tramadol.

In conclusion, this complication of SCD is uncommon but other reported cases along with ours serve to emphasize the need and desire for recognizing skull infarction, perhaps resulting in subperiosteal hematomas as causes of skull swellings and headache in sickle cell patients.

\section{Patient consent}

Consent was obtained from the patient.

\section{Ethical approval}

Ethical approval was obtained from Sudan Federal Ministry of health.

\section{Financial disclosure}

No funds or financial aid were received for this study.

\section{Conflict of interest}

All authors declare there are no conflicts of interest.

\section{Author contributions}

Case diagnosed and treatment supervision (ZIT), follow up (SEA, WME, SMEO), drafting of the manuscript (MEAE), analysis and interpretation (MMAH, HOA), critical revision of the manuscript for important intellectual content (MDY), study supervision (AAA).

\section{References}

[1] Alvarez OA, Hustace T, Voltaire M, Mantero A, Liberus U, Saint Fleur R. Newborn screening for sickle cell disease using point-of-care testing in low-income setting. Pediatrics 2019;144(4):e20184105. doi:10.1542/peds.2018-4105

[2] Du S, Lin C, Tao YX. Updated mechanisms underlying sickle cell disease-associated pain. Neurosci Lett 2019;712:134471. doi:10.1016/j. neulet.2019.134471.

[3] Pace BS, Ofori-Acquah SF, Peterson KR. Sickle cell disease: genetics, cellular and molecular mechanisms, and therapies. Anemia 2012;2012:143594. doi:10.1155/2012/143594.

[4] Sabahelzain MM, Hamamy H. The ethnic distribution of sickle cell disease in Sudan. Pan Afr Med J 2014;18:13. doi:10.11604/ pamj.2014.18.13.3280.

[5] El-Hazmi MAF, Al-Hazmi AM, Warsy AS. Sickle cell disease in Middle East Arab countries. Indian J Med Res 2011;134(5):597-610. doi:10.4103/0971-5916.90984.

[6] Piel FB, Patil AP, Howes RE, Nyangiri OA, Gething PW, Williams TN, et al. Global distribution of the sickle cell gene and geographical confirmation of the malaria hypothesis. Nat Commun 2010;1:104. doi:10.1038/ncomms1104.

[7] Aguilar Martinez P, Angastiniotis M, Eleftheriou A, Gulbis B, Mañú Pereira MDM, Petrova-Benedict $R$, et al. Haemoglobinopathies in Europe: health \& migration policy perspectives. Orphanet J Rare Dis 2014;9:97. doi:10.1186/1750-1172-9-97.

[8] Serjeant GR. The natural history of sickle cell disease. Cold Spring Harb Perspect Med 2013;3(10):a011783. doi:10.1101/cshperspect. a011783.

[9] Solovieff N, Hartley SW, Baldwin CT, Klings ES, Gladwin MT, Taylor JG6th, et al. Ancestry of African Americans with sickle cell disease. Blood Cells Mol Dis 2011;47(1):41-45. doi:10.1016/j. bcmd.2011.04.002.

[10] Babiker HM, Schlebusch CM, Hassan HY, Jakobsson M. Genetic variation and population structure of Sudanese populations as indicated by 15 Identifiler sequence-tagged repeat (STR) loci. Investig Genet 2011;2(1):12. doi:10.1186/2041-2223-2-12.

[11] Akodu SO, Njokanma OF, Diaku-Akinwumi IN, Ubuane PO, Adediji UO. Acute soft head syndrome in children with sickle cell anaemia in lagos, Nigeria. Indian J Hematol Blood Transfus 2014;30(Suppl 1):67-69. doi:10.1007/s12288-013-0251-6.

[12] Elagib EM, Eltahir NIA, Essa Adam MEA, Yousif Haron MD, Mahmoud ZIT, Mohamed Yousif HH, et al. Catastrophic antiphospholipid syndrome in combination with SLE treated by Rituximab: a case report and literature review. Lupus: Open Access 2019;4(1):137.

[13] Bello-Manga H, DeBaun MR, Kassim AA. Epidemiology and treatment of relative anemia in children with sickle cell disease in subSaharan Africa. Expert Rev Hematol 2016;9(11):1031-1042. doi:10.1 080/17474086.2016.1240612.

[14] Alli NA, Wainwright RD, Mackinnon D, Poyiadjis S, Naidu G. Skull bone infarctive crisis and deep vein thrombosis in homozygous sickle cell disease- case report and review of the literature. Hematology 2007;12(2):169-174. doi:10.1080/10245330601111912.

[15] Phillips JK, Boyd R, Krockenberger MB, Burgio G. Progression of anemia and its relationship with renal function, blood pressure, and erythropoietin in rats with chronic kidney disease. Vet Clin Pathol 2015;44(3):342-354. doi:10.1111/vcp.12276.

[16] Moghe S, Pillai A, Guru KN, Nair PP. Idiopathic facial swelling secondary to sickle cell anaemia. BMJ Case Rep 2012;2012:bcr2012007132. doi:10.1136/bcr-2012-007132.

[17] Neves FS, Oliveira LS, Torres MG, Toralles MB, da Silva MC, Campos $\mathrm{Ml}$, et al. Evaluation of panoramic radiomorphometric indices related to low bone density in sickle cell disease. Osteoporos Int 2012;23(7):2037-2042. doi:10.1007/s00198-011-1810-z.

[18] Saito N, Nadgir RN, Flower EN, Sakai O. Clinical and radiologic manifestations of sickle cell disease in the head and neck. Radiographics 2010;30(4):1021-1034. doi:10.1148/rg.304095171. 